hyperbaric oxygenation. Intensive Care Med 2002;28(5): 559-63.

\section{Waiting Room medicine}

To the Editor: Winnipeg newspapers have recently picked up the battlecry that the current emergency care system does not work. It is now unacceptable and dangerous that patients wait hours to be seen and treated. In response, the Manitoba government has decided to do a 1-week audit of selected emergency charts to see what the problem is. It seems they have forgotten to talk to the frontline workers, who might have an idea about what the major issues are.

The primary issue, which has been documented extensively in the emergency medicine and health services literature, is outflow block and the resulting lack of available stretchers. The simple fact is, most emergency stretchers are filled with patients already admitted to other services and waiting for an inpatient bed.

As the government has promised the public, the days of Hallway Medicine are over. Fantastic! Let's move ahead into the new world of Waiting Room Medicine.

\section{Lisa Bryski, MD}

University of Manitoba

bryskilm@cc.UManitoba.ca

Advertisement

Abbot

Pediatric Biaxin

Square Bootlug, 4 clr.

Repeat of Jan.

\section{Role of SARS screening clinic in the ED}

To the Editor: Dr. Marcus Ong recently described an emergency physician's perspective on the "War on SARS" in Singapore. ${ }^{1}$ Fortunately, the strategy and tactics detailed were effective at that time. We know from the recent appearance of sporadic cases in Guangdong, China, that SARS has returned. ${ }^{2}$

The SARS crisis has had one positive outcome: it highlighted many of the unique challenges emergency departments (EDs) face in dealing with contagious diseases. In addition, the economic costs of the SARS outbreak demonstrate the need to upgrade EDs to a comprehensive and national standard, as described in the recent CAEP position statement. ${ }^{3}$

Overcrowding is a key factor that increases the risk of infectious disease transmission in EDs. Overcrowding is increasingly common in urban EDs, where large numbers of patients, some with potentially lethal infectious illnesses, squeeze together in waiting rooms and on stretchers in hallways, exposing ED staff and other patients and increasing the risk of initiating a new infectious outbreak.

Previous ED infection control guidelines are not adequate. ${ }^{4-6}$ Significant ED retrofitting and redesign is necessary to address future infectious disease threats. ${ }^{7}$ These proved useful in the Singapore and Hong Kong outbreaks. We strongly propose establishing "SARS screening clinics" or "fever clinics" such as those developed in Hong Kong and Singapore ${ }^{1}$ during the 2003 SARS outbreak. These units segregate and manage suspicious patients with fever, contact history, SARS or influenza-like symptoms, using a biohazard model that protects staff and patients.

Fever units should apply a universal and high level of protection by making use of redesigned triage areas, nega- tively pressurized consultation and resuscitation rooms and full personal protection - especially when ED staff are performing high-risk procedures. Efficiency of screening is enhanced by designating senior physicians, protective equipment and resources to the clinic, and the chance of cross infection within the department is also reduced.

Also important is a reliable followup system to prevent "missed" cases from falling through the cracks. ${ }^{8} \mathrm{We}$ cannot afford to lose a single staff member in the battle or to miss a single patient in the community.

We have adopted these principles and run such a "fever clinic" in our department. Realizing the threat of future infectious agents or bioterror events anywhere in the world, we think this is the right strategy to be instituted in other EDs. Because air travel makes these concerns global rather than local, cooperation between different departments, hospitals, nations and countries is critical.

\section{Wong Wing Nam,}

\section{MB BS, MRCSEd, MFSEM(RCSI)}

Medical Officer

Accident \& Emergency Department

United Christian Hospital

Hong Kong

\section{References}

1. Ong EHM. Wars on SARS: a Singapore experience. Can J Emerg Med 2004;6(1):31-7.

2. WHO Update 3: Announcement of suspected SARS case in southern China. Investigation of source of infection for confirmed case begins tomorrow. Available: www.who.int/csr/don/2004 _01_08/en/ (accessed 2004 Jan 16).

3. Ovens H, Thompson J, Lyver M, Murray $M J$, Innes $G$, on behalf of the Canadian Association of Emergency Physicians (CAEP). Implications of the SARS outbreak for Canadian emergency departments [position statement]. Can J Emerg Med 2003; 5(5):343-7. Available: www.caep.ca /004.cjem-jcmu/004-00.cjem/vol-5.2003 /vol-5.pff/v55-pf.343-7.htm (accessed 2004 Jan 16).

4. Canadian Association of Emergency 
Physicians. Guidelines for managing severe acute respiratory syndrome (SARS) in Canadian emergency departments. Available: www.caep.ca/002 .policies/002-01.guidelines/SARS/002-01c .SARS-EMguidelines.htm (accessed 2004 Jan 16).

5. Health Canada. Public health guidelines for infection control guidance for health care workers in health care facilities and other institutional settings. Available: www.hc-sc.gc.ca/pphb-dgspsp/sars-sras /prof_e.html (accessed 2003 Nov 3).

6. US Center of Disease Control \& Prevention. Updated interim domestic in- fection control guidance in the healthcare and community setting for patients with suspected SARS, updated 2003 May 1. Available: www.cdc.gov/ncidod /sars/infectioncontrol.htm (accessed 2004 Jan 16).

7. Thompson J. SARS: finding a deadly needle in the haystack [editorial]. Can J Emerg Med 2003;5(6):392-3.

8. Wong WN, Sek ACH, Lau RFL, Li KM, Leung JKS, Tse ML, et al. Accuracy of clinical diagnosis versus the World Health Organization case definition in the Amoy Garden SARS cohort. Can J Emerg Med 2003;5(6):384-91.

\section{Correction}

In the Controversies article "War on SARS: a Singapore experience" by Marcus Ong, published in the January 2004 issue of CJEM (CAn J Emerg Med 2004;6[1]:31-7), the wrong French résumé was inadvertently published with the article. The English abstract is correct. We apologize for this error. The correct French résumé is reproduced here.

\section{RÉSUMÉ}

Le 12 mars 2003, I'Organisation Mondiale de la Santé a émis une alerte globale concernant des cas de pneumonie atypique sévère appelée "syndrome respiratoire aigu sévère " (ou SRAS). À Singapour seulement, il y a eu 238 cas de SRAS et 33 décès, y compris cinq travailleurs de la santé. L'interconnectivité planétaire étant maintenant une réalité, le SRAS s'est propagé rapidement pour devenir un phénomène mondial. Le présent article décrit la " guerre contre le SRAS " à Singapour du point de vue d'un médecin d'urgence, en mettant l'emphase sur la stratégie de " prévention, détection et isolement ". Des innovations remarquables comprennent le recours aux ordres de quarantaine à domicile, le dépistage de masse de cas de fièvre à l'aide de l'imagerie thermique, des systèmes modulaires de dotation en personnel à l'hôpital, des visites d'hôpital virtuelles et des innovations dans la configuration du département d'urgence. La plupart des départements d'urgence, hôpitaux et systèmes de santé ne sont pas préparés sur le plan psychologique et logistique à faire face à une épidémie majeure d'une maladie infectieuse. À la lumière des menaces naturelles et terroristes récentes, les dispensateurs de soins d'urgence à travers le monde doivent adopter un nouveau paradigme. L'épidémie récente de SRAS n'est peut-être qu'un avant-goût de ce qui nous attend. 